\title{
Deaths of the Subject and Negated Subjectivity in the Era of Neoliberal Capitalism
}

\author{
Daniel Rueda Garrido
}

Hebei Normal University, Shijiazhuang, China, danigares_es@yahoo.es

\begin{abstract}
In recent years, various descriptions of subjectivity related to the era of neoliberal capitalism have been offered. These descriptions assume uncritically that there is both a subjectivity of this time and a qualified subject to which it corresponds. The contrast of these descriptions with the claims of postmodernist authors regarding the death of the subject posits a contradiction. In this article, a solution to this problem is provided by the support of the dialectic of Sartre's realistic materialism. The application of the dialectic sheds light on the neoliberal individual, who, integrated as a negated subject in the totality of the neoliberal order, shows itself as a reified individual without subjectivity, or rather, with a negated subjectivity. From that it follows, opposed to a rather widely accepted definition, that subjectivity is not a positive characterisation but rather the negativity of the reified form of life within neoliberal capitalism.
\end{abstract}

Keywords: neoliberal subjectivity, neoliberal capitalism, Sartre's dialectics, deaths of the subject, global market, consumerism

Acknowledgement: My gratitude to Christian Fuchs, Wayne Hope and the anonymous reviewer for their insightful comments and useful suggestions on previous versions of this article.

"If you wish to leave the game, you must save Jumanji and call out its name" (Jumanji 2017)

\section{Introduction}

Is there a neoliberal subjectivity? Is there subjectivity at all? The attempt to answer these two questions will guide the course of my investigation in this article. The first question has been answered affirmatively, at least implicitly, by an increasingly extensive bibliography on the topic. In this way, when answering the first question, certain authors assume the existence of subjectivity, so in turn responding positively to the second question, which, precisely because it has a more philosophical nature, requires a critical and not merely assertive approach.

I begin this article by giving an account of the most accepted contemporary description of neoliberal subjectivity and, in doing so, I assume the existence of both the subject and a neoliberal subjectivity. However, by contrasting the proposal of neoliberal subjectivity with postmodernist and poststructuralist affirmations, in the era of neoliberal capitalism, about the death of the subject, besides the claims of reification of the subject within the Marxist tradition, a moment of contradiction is obtained that only a dialectical approach can solve. The dialectic rehabilitated by Sartre (2004/1960) serves to resolve this impasse by identifying the neoliberal individual as a denied subject (incomplete, desiring) within a process that shows the totalising unity in a dialectical relationship with its internal moments. As the dialectic 
of realistic materialism suggests, by means of negations, the totality approaches the last moment of identification with itself as a realised totality and without internal contradictions. In the historical process commencing from the 1970s, the neoliberal capitalist order as a whole has progressed in the reification of the subject, from its first negation, as for part of capitalism. Thus it is understood that the totalising process makes reference to capitalism as such, of which neoliberal capitalism is just an advanced phase of greater integration of members in the totality, in terms of reification, that is, of the commodification of the subject and its world. In subsequent sections, I show how this process of reification has been formed in two fundamental aspects:

1. The integration of the individual in the totality as a positive determination of the logic of the market, aimed at an increasing reification of its desire, its freedom, its creativity and, finally, its identity.

2. The homogenisation of the reified individual and negation of the subject, understood in its capacity for self-sufficiency and completeness, which are implicit in the terms autonomous, free, creative and rational, and are denied in its denial; and together with its denial, at the last moment of the neoliberal era that we are living, the progressive denial of everything that the subject holds (the law, democracy, individuality, nature, etc.).

This analysis leads me to conclude that, although the subject has died, denied by the totalising process of the global market (and for poststructuralists by epistemological reasons), it maintains a spectral survival as the negativity (denied subject) of the object which the individual has become. Thus, I show that so-called neoliberal subjectivity is no such thing, because where there is no subject, there cannot be subjectivity (it cannot be positive in presence, but only in absence, as a lack of its properties); what is understood by neoliberal subjectivity is nothing more than the characteristics of the external performance imposed by the neoliberal order onto individuals; and that, furthermore, in the neoliberal era, the subject has intensified its integration through new technologies of information and communication allied with an essential consumerist lifestyle, being reified not only in their labour and personal relationships (proper to capitalism), but in their own creativity as the imaginative faculty, their feelings and, even more, in their own identity (a feature exacerbated within neoliberal, digital and global capitalism). Finally, having before us this scenario in which only the final realisation can end capitalism as a totalising process, it is incongruous to propose an immediate alternative; all that can be done is to glimpse a future society, on the ruins of capitalism, as the condition of possibility for the birth of the subject, and that is what I turn to in the conclusion of this article.

\section{A Contemporary Account of Neoliberal Subjectivity}

If by subjectivity we understand the subject's form of life, which represents the individual in its bidirectional relationship with its situation and with other individuals, then what the individual is will necessarily be conditioned by its environment and, in particular, by social and political organisation. The subject is defined by way of being in society, in the polis. Therefore, the politics and the economic policy implemented in the polis allow the appearance of one and not of another type of citizen, with certain subjectivity. This is what Aristotle maintained in book III of his Politics (Aristotle $1959,1275 b)$ and what McGuigan seems to want to express when, quoting Margaret Thatcher, he points out the emergence of a new way of being in relation to the neoliberal policies promoted in the 1970s: "The following observations are inspired by Margaret Thatcher's notorious description of her own politics in 1981 when she 
remarked that the method is economic but the object is to change the soul" (2014, 224). The change of regime implies a transformation in the citizens' form of life, or, in Thatcher's terms, in their souls. According to this, the subjectivity of citizens depends on the political-economic regime and can be understood as an expression of the way in which the subject experiences its life.

In that very same sense, Foucault understood the new tendencies of neoliberal capitalism at the time he delivered his seminar on contemporary subjectivity, which has been published with the title of The Birth of Biopolitics (Foucault 2008/2004). Foucault at that early period had already conceived neoliberalism as a strategy to rule, that is, a regime: "Following Foucault to the letter, Brown sees neoliberalism as a governmental regime that sets the rules of conduct in all spheres of life and, moreover, she believes it needs little in the way of ideological support to sustain the operations of power" (McGuigan 2014, 229). Although together with Foucault's view stated in the above quotation some authors maintain that neoliberalism has to do with the regulation and reorganisation of praxis $^{1}$, the prevailing framework represented by authors such as David Harvey has tended to identify neoliberalism in a wider fashion as an ideology that "frames the meaning of everyday reality for people" (quoted in McGuigan 2014, 225). Therefore, what must be retained from the above is that:

1. Neoliberalism is a pervading ideology that shapes to the very core people's lives, regulating their praxis, thoughts, language and so on, and

2. Neoliberal subjectivity has to do with that instilled form of life and how people experience it.

But what is neoliberal capitalism in historical terms anyway? In order to set out the timeline of these changes in politics and in the people's "soul", we must note that although it can become much more of a complex matter to distinguish historical periods within the development of capitalism, the changes that affect our topic don't go beyond the 1970s. I follow McGuigan in his brief approach to the history of neoliberalism as an evolution within capitalism. The phases stated by other authors like Harvey are the following:

1st Phase (1900): began as liberal capitalism around the turn of the century; private investment in a free market led to serious irregularities in transactions with the subsequent exorbitant economic growth of certain companies and the unsustainability of the stock market, ending in the crack of 1929.

2nd Phase: after the crisis of 1929, the liberalisation of the market was restricted by an economic protectionism that has been called "organised capitalism" (McGuigan 2014, 224; while Harvey $(2005,11)$ referring to the same phenomenon prefers the term "embedded liberalism") with some state intervention in the 1930s and in the aftermath of the Second World War.

3rd Phase: at this time there is again a return to the previous liberal capitalism (1970) and so-called neoliberalism (although with its own characteristics) which continues to

1 It must be remarked that Mitchell Dean (2017) has claimed recently that it is a misconception to attribute to Foucault an outline of neoliberal subjectivity, as what the French philosopher insisted on was in envisaging neoliberalism as a mode of liberation from governmentality, that is, a way out of subjectification. In subsequent sections of this article I take up this argument to develop my proposal. 
this day, when we have a broader and globalising version of neoliberal capitalism (McGuigan 2014, 226).

From this short review of the historical formation of neoliberalism, I would like to emphasise that the passage from organised capitalism to neoliberalism proper took place due to a depletion of previous policies to produce wealth and stability, which provided the trigger for Thatcher's and Reagan's policies with the promotion by the British Prime Minister of the well-known slogan TINA: "there is no alternative". The situation, as McGuigan mentions, was uniquely the oil export crisis in 1973, declared by the OPEC (Organization of Petroleum-Exporting Countries), and the deficiencies shown by the Fordist production system (Fordism) to be able to create and satisfy increasing demand as well as to get rid of machinery and part of the national production chain and find cheaper markets to produce and place their products (McGuigan 2006, 73). However, as Agnew has remarked, those changes were supported by the implementations of certain approaches of the US in terms of economic policies pointing to globalisation; for instance, the increased levels of international trade in the 1960s and the US abrogation of the Bretton Woods Agreement of 1944, which liberated currencies from a fixed exchange rate to the US dollar, thus making possible, by deteriorating their own economy, the construction of an international market where currencies "could float against one another", which is today's globalised financial system (Agnew 2005, 169). Since 1980, the implementation of neoliberalism has managed to impose itself as a hegemonic mode of development, and with greater intensity since the fall of the Soviet Union in 1989. With the coming of the 21st century and new technologies of digital communication, new modes of exploitation and expansion of capital have arisen, in what has been called global and digital capitalism. This hegemony of neoliberalism knows no boundaries and can be defined by what Harvey (2005, 3-4) and Agnew $(2005,165)$ understand as a time-space compression of the market; the global market, already identified with the daily life of the citizen, is within reach of the computer mouse: people, countries, transactions and things seem to be omnipresent when this new digital citizen connects to the network.

This citizen, produced by neoliberal policies and exacerbated by digital technologies, has been identified with a certain positive subjectivity; that is, a way of being and of understanding oneself by affirming one's intrinsic qualities. McGuigan draws on Weber's ideal type to cast the type of neoliberal self; ideal types "are abstract formulations that do not exactly conform to any particular empirical instance. They are defined, in the Weberian sense, by essential features that are accentuated in order to bring out the most salient aspects of a given form of life" $(2014,233)$. These ideal types, according to the same author, must necessarily be proposed in contrast to their historical context, in Simmel's historicist mode. This means that the ideal type of the self or neoliberal subject has to emerge from the same social and political organisation that the neoliberal order has established. It is important to underline this notion to understand how the ideal type of neoliberal subject being cast here is the product of the social structures determined by the evolution of capitalism as a whole. I will return to this in the following sections. Most studies on neoliberal subjectivity mention at least the characteristics of compulsory freedom, individualism, self-realisation (creation) and hedonism (narcissism) in relation to the market or consumerism. 


\subsection{Condemned to Freedom and Self-Responsibility}

It is usually agreed that the neoliberal self is a self that is condemned to freedom and to be responsible for its actions. Of course, the major premise in this argumentation is the assumption that the self is free, or has been liberated from past ties of a religious, moral or philosophical nature. This responsibility does not imply moral values; one is responsible because one is free. Freedom implies responsibility and this involves blame for failure or praise for success in both consuming rationally and enterprising effectively, or in McGuigan's words: "such a self - condemned to freedom and lonely responsibility - is exactly the kind of self cultivated by neoliberalism, combining freewheeling consumer sovereignty with enterprising business acumen" (McGuigan 2014, 234).

\subsection{Individuality (Egotism)}

The literature on this subject (Blühdorn 2017; Dean J. 2017; McGuigan 2014) tends to reinforce the feature of individualism in the neoliberal self, though in relation to previous generations within capitalism. This individualism is concerned more sharply with young people and materialises as passivity regarding social issues, as social atomicity, as communication through new technologies, and so on. This individualism seems to be equally imposed structurally, because the neoliberal subject is obliged to take care of him/herself and procure the means that lead him/her to success in a society that is always more aggressively competitive: "in a viciously competitive job market we have no choice but to work on ourselves, constantly, just to keep up" (Dean J. 2017, 3). And yet, as Castells pointed out years ago, in the "information age', from the 1990s onwards and above all with digital communication technologies, this individualistic subjectivity clearly enters into conflict with the interconnectivity of the masses in the network (McGuigan 2014, 231). This first discordant note makes us wonder if there is truly a clearly-defined neoliberal subjectivity and if, in any case, individualism is a characteristic of this subjectivity or a product of the global market in which the subject has necessarily been incorporated as an individual entity that, in terms of the consumer, reproduces the logic of the market.

\subsection{Self-Realisation (Liquidity)}

It seems as if, in the era of neoliberalism, everything solid has melted, as per a metaphor borrowed from Zygmunt Bauman (2000). And the truth is that this is one of the characteristics that this period shares with so-called postmodernism, a label whose value overlaps with that of neoliberal policies after the 1970s; and in such a way that we could refer to it as the cultural face of what would otherwise be the political and economic order. This connection between the culture and the economy of the decades that concern us has been prominently stated by Fredric Jameson $(1998,73)$. The identity of the subject, the self, like everything else, is considered volatile, ephemeral, opening a tendency to self-invention or creation of oneself. Individuals are constantly driven by social media and labour pressure to work on themselves, adopting different patterns of personal and professional success, as well as being encouraged to adopt different identities (perhaps latent or asleep, perhaps repressed) by consuming products with which they identify themselves. And, as Jodi Dean puts it, "each is told, repeatedly, that she is unique and encouraged to cultivate this uniqueness. We learn to insist on and enjoy our difference, intensifying processes of self-individuation. No one else is like us (like me)" (2017, 3). Perhaps it is in the digital age that this feature attributed to neoliberal subjectivity is best 
observed. The individual invents himself or projects his identity, perhaps his most intimate convictions, through the network set by the digital filter.

\subsection{Hedonism (Narcissism)}

According to McGuigan and other references (Blühdorn 2017; Dean J. 2017; Harvey 2005), the neoliberal self is hedonistic and flexible, in instant transformations, with a cool-capitalist detachment or disaffection: "Such hedonism is connected to a "coolcapitalist' cultural formation that performs an astonishing ideological trick [...] by incorporating signs and symbols of disaffection, affecting a rebellious posture, as in the case of Apple, to popular and extremely profitable effect" (McGuigan 2014, 232). Hedonism is seen as the way in which the individual expresses her social dissatisfaction, which to some extent can be considered part of the politically correct; the hedonist is the one who seeks pleasure and satisfaction but complains when she does not find it and claims it as a violated right. This dissatisfaction leads to a socially accepted attitude of protest, at least as a rebellious posture, because it is estimated that the consumer and welfare society cannot afford dissatisfaction.

Ingolfur Blühdorn has established a relationship between neoliberal subjectivity and the modern project of emancipation, referring to it as a second-order emancipation that "implies, firstly, the rejection of earlier ideals of subjectivity which are now experienced as too restrictive and, secondly, a much more open-minded reassessment of aspirations, practices and lifestyles which had formerly been portrayed as corrupting character, mutilating the authentic Self, repressive or as false consciousness" $(2017,10)$. Precisely what seems to be rejected in this second order emancipation is the modern subject with its characteristics of identity, unity, autonomy, plenitude, and so on. That is, in this attempt to overcome rigid schemes of subjectification of the past (a past that refers not only to history but to the politicaleconomic regime of the modernity in which it emerged), that very subject survives as a negativity, a sort of living dead. This will be the content of the following sections of this article.

\section{Neoliberal Subjectivity and the Deaths of the Subject}

Although the literature on the topic seems to agree on the existence of a neoliberal subjectivity, there are still questions that we need to deal with if we want to prove the review I have provided above to be consistent and legitimate. Is it still appropriate to embrace the concept of neoliberal subjectivity after postmodernists' (and poststructuralists') claim of the death of the subject? Is there subjectivity at all?

We could ignore the voices that from the middle of the twentieth century, and especially in line with what would later be called post-modernism, impelled us to realise that the subject had died and consequently to abandon all social and personal conceptualisation (cultural, aesthetics, etc.) in relation to it. But even if we did, or if we tried to ignore those voices, it seems doubtful that we would succeed, because our Western culture, and also I suggest the global culture, to the rhythm of the globalisation of neoliberal capitalism, shows clear symptoms that the subject has certainly died, and yet, as living dead, it continues in spectral ways to appear in our daily life and the very organisation of post-industrial society. In the review of the features of the neoliberal subject, I have ventured some nuances to that conceptualisation of subjectivity, which I claim rather refers to the roles that citizens play in this increasingly advanced game of neoliberal capitalism. But before exploring in what way the subject or subjects have been able to survive, we will examine how their various deaths or their slow deaths were caused from multiple flanks. 
According to Schmidt, the death of the subject claimed by the first poststructuralists was based on Heidegger's thought expressed in the aphoristic statement "Der Mensch ist ein Versprechen der Sprache", where the ambivalent meaning of "Versprechen" is both 'slip of the tongue' and 'promise'. That is what makes Schmidt write that "Man was, according to Heidegger, always already both a failure and a promise. The project of overcoming humanism in language, discourse, and the cultural sciences was not only a misunderstanding" (Schmidt 2014, 2). Heidegger can be traced, together with Nietzsche, as the precursor of postmodernist thinkers at least in what refers to the death of the subject. The "Man" was then to be overcome for both German philosophers, for, as subject, it was the support and foundation of a worldview that was against life and against existence (the decadent man in Nietzsche). That is what Heartfield fails to notice after explaining accurately the genealogy of criticism of the subject in relation to nineteenth century historicism (from Hegel onwards), when he affirms that criticism against the subject was not sufficient for these thinkers, and that the elimination of the subject was taken as something given, without an explicit justification: "Their approach was to substitute the temporal contingency of the subject for an argument [...] Why the thing being criticized ought to be rejected does not need to be stated. It is the kind of criticism popularly expressed in the phrase 'that's so old'" (Heartfield 2006/2002, 27). For Foucault, whose work is representative of the beginning of the death of the subject in poststructuralist accounts, the reason to get rid of the man as modern subject is precisely that as such it is a product of a paradigm (of scientific knowledge) or episteme relative to modern times; an episteme that was already changing in the twentieth century. His task was to show this genealogy of the modern episteme and its end. In Foucault's words, "as the archaeology of our thought easily shows, man is an invention of recent date. And one perhaps nearing its end" (1971/1966, 385). Foucault is undoubtedly the beginning of this symptomatic process of the dissolution of the modern subject, a subject that was, as Blühdorn (2017) has also pointed out recently, inscribed in the foundations of the Enlightenment project of autonomy, freedom and responsibility (Sapere aude!). Also from the epistemology Lyotard gives his farewell to that subject, the epitome of a whole era, which ended with him. Lyotard, therefore, defines the stage that opens up as postmodernism, and characterises it as the end of the great metanarratives, that is, those great stories that have been imposed to explain the world and give a meaning to human life in an exclusive way, displacing other stories to the margins of history. Among them, perhaps the most fundamental was the metanarrative of the subject as a unitary, rational and autonomous being, rooted in the Christian subjectivity (see Motzkin 2014): "I define postmodernism as incredulity towards metanarratives" (Lyotard 1989, 16).

From the deconstructive line opened by Derrida, the subject had to be deconstructed; Derrida not only tried to show that there are differences between different individuals and that it is, therefore, illegitimate to insist on a concept of a universal and homogenous subject; his proposal went further: the deconstruction of the subject was to eliminate the assumption that there was a subject and then, by comparison with others, their different features were identified. It was for Derrida precisely the difference or différance that was primordially prior to the subject. This thought regarded in the denial of the subject an openness to the plurality of ways of being and of understanding oneself. With respect to sociological accounts, the subject in the second half of the twentieth century fared no better, and it was negated as a prior entity to the formation of society. The subject for Althusser doesn't exist 
without society (Heartfield 2006/2002, 16). Bourdieu would say sometime afterwards that the subject or individual autonomy and freedom is an illusion produced by the coincidence of phenomenological experience and social structure (1990, 25-26).

It is evident that the modern subject with its properties has been denied from many different fields: as roughly mentioned above, sociology and cultural studies state that the human being is an effect of environmental conditions; biological science describes human being in terms of deterministic process and causal relations between our neurons and thinking or emotions, and between genetics and personal features; psychology states that family life determines behaviour, and economy proposes globalisation and the market as the logic of human behaviour. And yet, the subject continues to exist as living dead, perhaps denied to convince ourselves that the behaviour we actually accept is inevitable, an attitude that Sartre called "bad faith" (Heartfield 2006/2002, 238). My thesis, evolved in the following sections, is that this subject goes on living in the era of neoliberal capitalism, although it lives in denial, that is, denied as subject and affirmed as a part of the capitalist form of life in terms of a progressive reification, in line with Marxist tradition.

\subsection{The Death of the Subject and Sartre's Dialectical Reason}

To examine in what sense one can speak of the subjectivity of neoliberalism and what that spectral life of the subject is like, it is necessary to do so from a critical standpoint, and as we speak of a subject denied by postmodernity and of a subjectivity that may or may not exist in the sense in which it has been exposed above, we are expressing a dialectical relation between a thesis and its negation. It is precisely because the object of our study is presented to us in a dialectical way that we are led to apply the dialectical reason enabled by Jean-Paul Sartre (2004/1960).

The dialectical reason is a method that seeks to critically establish the knowledge of the historical reality in which the subject lives while submitting to judgment the same subject who carries out that knowledge as a product of that reality: "It should be recalled that the crucial discovery of dialectical investigation is that man is 'mediated' by things to the same extent as things are 'mediated' by man" (Sartre $2004 / 1960,79)$. In this way, Sartre criticised the external dialectic because it provides for historical reality a blind evolutionary law through transcendental opposites that gives rise to a capricious process. Sartre's dialectic sought to establish the existential conditions by which the dialectical movement of history gained intelligibility: "The dialectic, however, if it is to be a reason rather than a blind law, must appear as untranscendable intelligibility" (Sartre 2004/1960, 37). It was conceived, in short, to explore the dialectical relations internal to the object of study itself, to understand how this object is formed and in turn opposed to another or others. The internal dialectic, a dialectic that tries to correct the dialectic idealism of Hegel and Engels, is a realistic materialism. And with it, the object of study is made to show its own internal contradictions that explain its formation and progress. This means that the first step for dialectical study is to understand the object as a whole, at least as a future whole in its dialectical evolution of oppositions.

The first aspect worth highlighting for our purposes is, in effect, that the whole determines its particulars. The importance of this notion lies in the particular realities, first, that to be able to oppose each other, both must be under the same unit; and second, that both opposites can neither be understood abstractly outside of that confrontation nor outside the totality or totalisation movement in which they have arisen: "On this basis, a dialectical logic of negation conceived as the relation of internal structures both to each other and to the whole within a complete totality or 
within a developing totalization, could be constructed" (Sartre 2004/1960, 86). The particulars confronted are determinations of the totality, and, as determinations, they are negations of the totality (following Spinoza, who considered that all determinations are negations). The totality in this sense is prior to the parts; although the parts give rise to the totality in its evolution, they are parts because they belong to a totality, and are therefore determined in their own structure and identity by the totality of which they are part (Sartre 2004/1960, 86).

In the development of the object as a whole, its internal determinations are based on one of the principles that Engels identified as laws of historical development: the negation of a negation within the unit (Engels 1940, 26). The first negation is that of the part by which the totality denies itself; therefore all determination is a negation of the totality. Through this dialectical principle, the first negation is in turn denied by the determined totality itself as opposed to the first negation. Double denial leads to an affirmation. And this is, in turn, in a later movement, placed as a negation to be denied: "And it is within the totality, as the abstract unity of a field of forces and tension, that the negation of a negation becomes an affirmation" (Sartre 2004/1960, 86). That negation of a negation expresses a process of integration of the parts within the totality and the movement of totalisation. Thus, we must understand the affirmation as an integrating moment by which the whole is self-completing and points to the consummation of all its determinations: "[...] negation is defined on the basis of a primary force, as an opposing force of integration, and in relation to a future totality as the destiny or end of the totalizing movement" (Sartre 2004/1960, 85). It is then that we understand Sartre's negation of man as an abstract entity; man (or subject) exists but as posited by a totality, that is, within a particular existential condition given by the whole totalising movement of which it is a part.

Furthermore, it must be understood that there is no such thing as man; there are people, wholly defined by their society and by the historical movement which carries them along; if we do not wish the dialectic to become a divine law again, a metaphysical fate, it must proceed from individuals and not from some kind of supra-individual ensemble (Sartre 2004/1960, 36).

The subject, which is the core of our research, from Sartre's dialectical reason, is a being that exists within a totality, which has to be posited as the one that gives to it a certain identity (existentialist totalisation, in Jay 1984, 331-360). That also means that it is not possible to study the totality in the abstract without the individual that it has produced: the beginning of the investigation must, therefore, be the individual, or what the subject is as determined by its historical moment and its economic-political regime. In this sense Foucault was also right when he reversed the eighteenth century's thought of free men in the state of nature from which emerged the civil society, stating that it was from civil society that the free individual emerged (Heartfield 2006/2002, 23-24). Foucault's idea can be linked to the reference to Aristotle made in the first section of the present article, according to which the regime of government produces a certain type of citizen (Aristotle 1959,1275b). For Aristotle, man could only be fully realised as a citizen of a good political regime; it was not possible to be good entirely independent of the political organisation in which he was born. If this is the case, we are ready now to extract some consequences from the dialectical reasoning for neoliberal subjectivity.

The dialectical reason, as rehabilitated by Sartre, proposes that the object of study, the subject, has to be put into a dialectical relationship of internal 
determination with a totality, which is in turn what produces this subject; that is, the economic-political regime. When we refer to neoliberal subjectivity, it seems obvious that we are determining the subject of that subjectivity in relation to neoliberalism. This reasoning leads us to establish neoliberalism as a regime, and, although it may seem surprising, especially when put in relation to Western liberal democracy, neoliberalism has to be studied not only as an economic theory but as an entire economic and political regime as, on the other hand, Foucault himself understood it (Verdouw 2017). That means that capital neoliberalism from the 1970s, as studied in previous sections of this article, produced an idiosyncratic neoliberal individual. To establish what this subject is like, one must understand neoliberal capitalism as a totalising process, already contained in its origins of classical capitalism, of expanding the borders of a free market and increasing the conversion and accumulation of capital. Understanding it in this way sheds light on its internal determinations and specifies the direction of the process as the integration of those affirmative moments within the totality, through the identification with the neoliberal market as pure exchange value.

In this last sense, neoliberal capitalism, seeking its total integration, continues to posit a subject that in spite of being subject and therefore having value in itself, requires or feels the material need of objects and their exchange value; a subject, in short, posited as incomplete, dependent and needy, seeking to complete its inherent need with an external object. This subject is the negation of the totality at least in the sense that it feels the lack of the material and wishes to be completed with an object; while the end of the totalising process is the absence of desire and the objectification of all its elements. The subject in need, and therefore incomplete, is integrated into the neoliberal order through the denial that the product represents with respect to its posited need to be completed. Necessity and consequent desire are denied by the acquisition of the product (Wagler 2009). This double negation leads the subject to its irrevocable integration into the totality as a consumer. The subject, already denied from the outset as an autonomous, free and rational subject by the totality, is again denied as a desiring subject; however, its condition of incompleteness will be the engine of subsequent negations and integrating moments in the neoliberal capitalist order. If we compare neoliberal capitalism as a regime of government with democracy, following the same dialectical reasoning, it can be understood why, while capitalism is not in principle contradictory with democratic principles, (neo)liberal capitalism $^{2}$ is, for it expands the market to the whole society, changing the form of life of the demos. That is, while democracy as a totality or totalising project that leads to the perfect government of the people over themselves posits an independent, complete and rational subject; the (neo)liberal order conducts its integration starting from a dependent, incomplete and desiring subject. In this sense, the point of departure, and even the ultimate destination, of democracy and neoliberalism are antinomian and impossible to combine to their ultimate consequences, despite Fukuyama's defence of their successful and eternal alliance (1992). It is not unreasonable, of course, to admit that Western democracy today is not the perfect companion to neoliberal capitalism, when non-democratic countries (for instance, Saudi Arabia or China) are currently developing economically at a vertiginous pace driven by their neoliberal policies.

${ }^{2}$ I refer to the neoliberal capitalism implemented from 1970 s as a continuation to the liberal principles carried out within the nineteenth century and the first decades of the twentieth century. 
As the capitalist neoliberal order can be identified with the globalising market, the dialectic that we should account for is rather that of the subject (part) and the global market as an object (totality). This can be described as the progressive death of the subject through the reification or commodification process. The process can be described as a continuation of nineteenth-century capitalism; and it has continued with especial intensity (although as mentioned above, it was made possible due to the economic strategies carried out during previous decades) since at least the 1970 s to this day. As an object of study, neoliberalism has developed over these decades, determining its internal moments fundamentally based on the incompleteness of the subject as a negated subject. This process can be studied in four moments: the first fundamental determination, and three others that deepen in the attainment of the integration of the negated subject in the neoliberal order and present its ultimate destiny as an object of the global market itself. The first two moments describe the reification process of the subject, first as an incomplete subject which establishes itself as a satisfied consumer and, secondly, as a subject constrained by the imposition of the object. The next two moments correspond to the first decades of the twenty-first century, in which digital communication technologies and the virtual world are developed. In these decades, although prepared by previous moments, there is an intensification of both the demand for self-creation of the individual and its alienation in social networks and virtual games.

\subsubsection{The Reification Process in Capitalist Society}

The term reification comes from the writings of Karl Marx and has been used in different ways since then, mainly within the Marxist tradition, although in a more general sense it has moved on to other dimensions of culture such as literary works; for instance, Houellebecq's novels (Honneth 2008, 18-19). Although it had already been referred to in early works of Marx, it is considered to make its first appearance in the first volume of Capital (1867). There, reification is established as the process by which the relationship between people becomes a relationship between things.

There it is a definite social relation between men, that assumes, in their eyes, the fantastic form of a relation between things [...] This I call the Fetishism which attaches itself to the products of labour, so soon as they are produced as commodities, and which is therefore inseparable from the production of commodities" (Marx and Engels 2010/1867, 83).

The reifying process in Marx can be completely linked to the concepts of exchange value and commodity fetishism. The relationship between the producer and the owner is a relationship between things, precisely because the worker's labour power is standardised in the exchange value of the produced object, which happens to be perceived as a fetish, isolated from the production process and the producer (as when a part is seen isolated from the whole), and instead, valued according to its relationship with other objects in the market. The owner thinks about the worker's labour power in terms of the exchange value of his/her products or the relation between the objects and not between the people: thus the producer/worker is reified while his/her work or labour power has been reified. As can be seen, the seed of the concept of reification is indissolubly rooted in the capitalist production system and Marx emphasises the reification of labour relations as the structure of capitalist society. 
But it would not be until Lukács coined the term in his History and the consciousness of the proletariat (1971/1923), and especially in one of the studies included in that work, "Reification and the consciousness of proletariat" (1922), that the term reification took on a meaning of greater importance with respect to the analysis of capitalist society and, in general, with regard to social and cultural studies, decisively influencing the first generation of the so-called Frankfurt School and the development of its critical theory: though without forgetting the great disagreements between these authors and Lukács.

In the first page of his essay, Lukács says that "reification" means "that a relation between people has taken on the character of a thing" (1971/1923, 83). This definition of reification connects it with Marx; that is, it expresses the objective dimension of reification related to the relations of objects in the market, but it is only with the incorporation of Weber's concept of rationalisation that Lukács completes its subjective dimension (How 2003, 65-66); reification is not just a way in which the subject thinks of others in terms of things and the calculations needed to control them for profit but is in fact at the core of the subject's consciousness, and it will be able to reify itself eventually. According to Lukács, the cause of this reification is, of course, the capitalist system of production in terms of the relationship between the values of commodities in the market and the aspiration to maximise profits in transactions. From the point of view of the phenomenology of the process, the subject becomes a reified being, lacking in commitment with respect to his/her surroundings and with the attitude of a passive observer, characteristics that for Lukács constitute a second nature $(1971 / 1923,89)$. However, this reifying process finds its redemption in the consciousness of the proletariat, who in breaking the illusory duality between the subject and its object will recompose the original unity in which the subject/proletarian, identified with the object of his/her work, reaches its own human value and reveals a praxis not corrupted by reification (1971/1923, 141-142). The Frankfurt school deepened the concept of reification associated with instrumental reason and extended it to all dimensions of capitalist society, especially to cultural manifestations, which both Adorno and Horkheimer call "culture industry". Fundamentally, these two authors take up the concepts of reification and commodity fetishism and focus their analysis on the consumer society of capitalism in the postwar phase (How 2003, 65).

The political and economic strategies carried out in the aftermath of the war propitiated what has been called neoliberal capitalism. Therefore, we must highlight the different way in which the reification identified by Marx and Lukács, as a structural phenomenon of the capitalist economy and society, is fulfilled in this last phase of capitalism. Firstly, while Lukács emphasises the reification of the social relationship of the workers and owners, which causes a praxis that replicates the instrumentalisation carried out by the worker who sells his labour power to obtain a benefit, in consumer society, certainly expanded and globalised from the 1970s, the emphasis is on the other end of the chain, not in the sale but in the purchase (not in the offer but in the demand). It is at this time, with the emergence of Fordist production, that citizens cease to be mere workers but also become large-scale consumers, which was true only of the ruling classes in the previous period. The reification is carried out mainly through the consumption of products that companies (through mass media) present as necessary for the consumer, as I will elaborate in the next section. Secondly, and related to the above, while in Lukács and Marx reification is fundamentally realised through the reification of the labour power of the proletarian class, in the post-war consumer society the reification is not only of the 
proletarian class but of all people, because society begins to be standardised through the consumption of products with which the consumer identifies. And thirdly, due to the homogenisation of the consumerist explosion and the cultural colonisation by the neoliberal policies of the 1970s, if, for Lukács, the proletarian class is the only one that as a true subject of history is called to revolution by means of class consciousness, by contrast, in the era of neoliberal and global capitalism, the hope has been fed that the multitude (which is no longer a concrete class, for the proletarians themselves are also owners), by becoming aware of the reification of their lives in all orders through consumerism (and the consumption of information and mass media in recent decades) and the progressive de-legitimisation of social institutions, will make the revolution and take the organs of power and control of society (Hardt and Negri 2009).

\subsubsection{Moments of Reification in the Era of Neoliberal Capitalism}

The first moment is the negation of the subject by the object within the neoliberal order as a global market. This moment can be identified around the 1970s with the neoliberal turn, but, of course, a first version was already partially in place in the nineteenth century, with then-called liberal capitalism, and afterwards from the 1960s, as stated by Agnew (2005,169), Harvey (2005, 2-3) and McGuigan (2014, 226-227). This first moment of reification is substantially shared by earlier periods of capitalism. The difference at first (other than the different ways in which reification is obtained) is in quantity, becoming a difference in quality as it changes the form of life, as Wittel remarks:

The capitalist market has become increasingly powerful, pervasive and hegemonic, the logic of the capitalist market colonises and destroys the logic of community, and [...] the market swallows more and more areas and aspects of life that hitherto have not been regulated by monetary measurement and monetary exchange $(2013,315)$.

That is, the global market reaches an ever greater portion of the society's population and pervades aspects of people's private life previously untouched. This is implemented through mass media and new technologies, starting with the invention of the television and the beginning of consumerism as an essential part of the people's form of life (Yuran 2019), the consumption of information as a commodity (Prodnik 2014, 155) being the core element of the political and economic initiatives carried out by the US from the 1960s in order to impose its culture and become the hegemonic power, as has been reviewed above (for culture as soft power, see Inayatullah 2013). The object (what is presented as exterior to the subject and the real opposition to the subject) is the market, and its negation of the subject entails a negated subjectivity; the subject holds itself as lacking something. The market creates in the subject a desire, which is otherwise translated as the need for something which is out of itself ${ }^{3}$ : the need for something to complete this sudden acknowledgement of incompleteness or scarcity (Gorz 1989). This phenomenon produced by the implementation of the logic of the market in society triggered the whole process towards the reification or commodification of everything within the

${ }^{3}$ In this sense, capitalism shows the shared origin of the Christian religion as stated by Max Weber (2005/1930), for it posits an incomplete subject, a subject that requires a (divine) aid to reach its completeness and that is theologically marked as an incomplete being (desiring but unsatisfied) through original sin. 
future totality, in terms of Sartre's dialectic, which is the absolute triumph of global capital. I would like to underline the importance of this phase for the whole subsequent process; it should be noted that once the subject is negated by the object producing the consciousness of incompleteness, the subject from that very moment becomes a negativity; that is, its subjectivity is that of a negated subject, and when that incompleteness is completed temporarily by a market product, that is, the negation of the first negation, the subject is no longer a subject but a consumer, and it has already passed over the threshold into the neoliberal order, being integrated within it, as Sartre put it, and in the logical movement towards its dissolution as a final moment of total integration or identification with the market and its logic: to render everything a commodity (Mason 2015).

The second moment is the reification of the subject's freedom. The subject sublimes its needs through an induced rationalising process. It is at this point when the subject, rendered consumer, identifies itself with the object based on reason. This identification has to do with the possibility of choosing between growing offers in the global market: "The latest such freedom [at time of writing] is the random selection of objects that will distinguish any individual from others" (Baudrillard 1988, 11). The consumer that as subject felt alienated and, more importantly, constrained by the restrictions of offers is then, once the need for such products is created, driven by the logic of the process to demand more variety of goods, translated as the liberation from the experience of unfreedom; in turn, this assumed liberation derives from the reification of the subject's freedom through the product chosen by the unleashed freedom of choice. Satisfaction and liberation are what the market offers to posit a consumer, otherwise a forever unsatisfied, incomplete and unfree subject. And we can notice with Baudrillard that by then the entire life has become a consumption field: "We have reached the point where 'consumption' has grasped the whole of life" $(1988,33)$. This process ended up establishing the free, rational consumer as a determination of the global market in its integrating cycle of negations of the subject in its various intrinsic aspects.

The third moment is the reification of creativity. This reification of creativity is to a certain extent also the reification of identity through objects of consumerism. As the consumer becomes rational and free through the freedom of choice, as it becomes more integrated within the market and increases the supply, it adopts the positive determination of the consumer who not only chooses between several products of the market but also creates the product and, in doing so, creates himself to a certain extent. Of course, this creation is made possible by a series of tools that the system offers, never by constructing the object with elements not offered and, therefore, outside the freedoms contemplated by the market; having thus the imagination confined within the limits of consumerist activities. Slavoj Žižek expresses it singularly in the following text:

Perhaps the properly frustrating dimension of this eternal stimulus to make free choices is best rendered by the situation of having to choose a product in online shopping, where one has to make an almost endless series of choices: if you want it with $X$, click $A$, if not, click $B$. We can go on making our small choices, "reinventing ourselves," on condition that these choices do not disturb the social and ideological balance (2002a, 542-543).

This consumer is the ideal type of entrepreneur, the one who efficiently makes decisions and creates its own style, adopting the logic of the market, and integrating 
itself more and more into the market through its own creation as an object. But at the same time, the entrepreneur continues to show its fundamental lack, which, on the one hand, makes possible the later moments of its development within the neoliberal order, and, on the other hand, is the target of continued, endless and useless attempts at satisfaction (for, as a subject with a positive subjectivity, the entrepreneur has been negated to become part of the totality).

The fourth moment is the reification of identity. The subject with its existential idiosyncrasy, that is, each being different from another, in the times of its final reification, becomes homogenised in several fashions. For Baudrillard, the identification with the objects is clear, even if not as clear as later in the digital era: "As the wolf-child becomes wolf by living among them, so are we becoming functional. We are living the period of the objects: that is, we live by their rhythm, according to their incessant cycles" $(1988,29)$. The subject becomes a new product in the market, a product exploited through the network. The enterprising consumer alienated in the products with which it has identified itself in previous moments now seeks to create itself as an object; if, before, it was the object of consumption on which its identity was projected, in this last moment of reification, it is the consumer, in the role of the Internet user, who becomes the object of consumption at different levels. It creates its whole life through the network, forums and social media minute by minute. It is in these moments of digital capitalism where the absence of the subject in its negation is more intensely perceived through the masks provided by the profiles of users and virtual role playing games, as Jameson pointed out in relation to postmodernism, the cultural side of capitalist neoliberalism: "postmodernity itself (the free play of masks and roles without content or substance)" (1998, 60). But even more than in virtual reality games or user profiles, the most typical mask of this digital age is that of the user's own face turned into an object (photos, videos, selfies, and so on) that increases or decreases its exchange value in the market depending on the visits to its place on the web or the likes and dislikes, the effect of comments and the reactions caused by the exposure of its life on social media such as Twitter, Facebook, Instagram, or Chinese Weibo, WeChat, and so on. What postmodernity is itself is a game of masks without substance (no subject, only masks that come and go for economic purposes); the mask is the reification of the subject, who looks no longer (masks don't look, don't have subjectivity) but is designed to be looked at by the market and surveillance system, the only subject of the global order. The life of the user thus replaces the life of the subject; its mask has become its true face; the user is the subject reified through its integration in the global/digital market game. Its human value becomes an exchange value in the digital world, where the consumer/user has been created entirely as an object, and where, as digital agent, it makes profitable its reification, often economically.

To illustrate my point, I will refer to a film which shows perfectly the characteristics of the objectification of the subject in this era. The film is Jumanji: Welcome to the Jungle (2017). If we are to distinguish more neatly between the subject and the determinations of the dialectical process within the totality that signifies the global market, we should say first that the subject is what is negated and the integrating role is what is affirmed. This entails that the subject experiences itself as a negation from the moment it enters within the logic of the market, when it consumes for the first time and becomes a consumer (because the neoliberal order constitutes the entire social life, one or another form of consumerism has become inevitable). This, as famously expressed by the film Jumanji, is the moment in which the subject enters in the game (in the film the characters literally enter inside the game), from which, once 
inside, nobody can leave unless the game is finished, evoking the lyrics of that famous song "Hotel California"; but with the allegory of Jumanji something else is implied: the game has an end. And this end of the game, even if it involves collaboration between the characters, who have all been transformed (reified) by the same game into other individuals (parts of the game), requires a winner and losers. When it has reached the end, all players, already fully integrated into the game and surrounded by mortal dangers, have to conjure the game by calling it by its name so as to break its spell. That is, the game calls its own name through the characters, and to call its own name is to know itself: only what has been completed as an integrated totality can be known (what is still in process cannot be known in its entire and final state). Can we think of a more accurate allegory to describe neoliberal capitalism, in which we are immersed as a totalising process?

Along with this process, the subject can be seen in its reification as a commodity within two parallel lines: firstly, while engaged within the global/digital market, which covers gradually more of the subject's life in terms of time and space (Agnew 2005; Harvey 2005), its positive determinations within the neoliberal order are that of a satisfied, free, creative identity bearer and user/consumer, which paradoxically leads to its absolute commodification by the logic of the market, which the user/consumer follows inherently in order to make of itself an object within the market. Secondly, the user/consumer as affirmation within the totalising process has its negativity, in Hegelian terms, which is the negated subject, a dead entity that is somehow still alive, as living dead, probably awaiting its last definitive stroke. This negated subject entails a subjectivity that is incomplete or unsatisfied, unfree, uncreative and lacking identity, that is, a negated subjectivity that only appears as an absence.

\subsubsection{The Final Death of the Subject and the Negation of its World}

This dialectic reason shows how the subjectivity of this era has been reified and put to work within a progressively omnipotent market, which becomes the very structure of the subject and its world. The subject has definitely been negated by the global market, deepened with some help of the subjects themselves in search of freedom, recognition and identity (absent subjectivity). At the height of 2016 something occurred in the world and we are still so astonished as to be unable to identify the meaning of it and articulate a coherent account. Following a dialectical approach, I aim to suggest an account by which the negation of the subject has reached its highest level so far, together with the negation of the terms related to the subject: those opposed to the object. For with Brexit and Trump's election, the object, namely the global market, has shown its power and dominion over international affairs. With the progressive negation of the subject, the object has undergone a sort of subjectification, by which the global market as object has appropriated some features of subjects, such as to decide and promote its own interests and values as well as to eliminate its obstacles. This is an object that behaves without reflection or proper subjectivity, following its internal principles and laws: borrowing Varoufakis' metaphor in The Global Minotaur, the global market has become the Minotaur (Varoufakis 2011) who has been fed with our subjectivities and our forms of life to become so powerful that in the period opening with 2016, as the literature on this shocking moment references, the world has changed into a more authoritarian one, more predisposed to negate the impediments to the fulfilment of the market's designs and interests (Fuchs 2017a). And not even stopping consumerism as the key of the whole process seems to be possible when the whole of society is already marching towards total reification, and all individuals are already within it playing a game which grants 
no exit until its end (for a more optimistic proposal, but one with which I disagree, see Sklair 2016, 23).

The absolute negation of the subject has particular consequences for related terms such as the individual, the state, the nation's interest and even nature and climate change. The subject is the foundation of the state, the law, democratic nations, international organisations, human rights and human aids. Without the subject as able to reflect autonomously on its behaviour and remaining conscious of itself and its own world, the objectifying action of the market has no limits. Each of the items mentioned seems to be negated together with the subject, and for the sake of their objectification as commodity. And the crucial point within the totalisation process in terms of integration is the homogenisation of every entity, together with the subject, in spite of the apparent multitude and plurality of changes propitiated by the global order, in what has been called by Jameson a modularity, which takes place

"where intensified change is enabled by standardization itself, where prefabricated modules, everywhere from the media to a henceforth standardized private life, from commodified nature to uniformity of equipment, allow miraculous rebuildings to succeed each other at will, as in fractal video" (1998, 57-58).

That is the subject (reified as an object) in these times: a module of the global order that reproduces the form of the whole more perfectly as it moves towards its ultimate dissolution in it: "What then dawns is the realization that no society has ever been so standardized as this one, and that the stream of human, social and historical temporality has never flowed quite so homogeneously" (Jameson 1998, 59).

The heterogeneity of the subject inherent to its particular existence is homogenised by this globalising and integrating process, and this gradual homogenisation can be seen equally at this stage in the predominance of the crowd (populism) over the individual, of the economic interests within the market, and the accumulation of capital over national interests in other aspects (especially important for its citizens such as quality employment and healthcare for all), the privatisation of natural assets, and the denial of nature as a problem (Hope 2018). It is particularly clear in the case of Donald Trump, who, together with other world leaders, has become the incarnation of the market itself, a state of affairs that has been underlined by a number of authors such as Sanford and Pavlovskaya: "Trump embodied neoliberalism, he lived and breathed the idea that government should be run like a business by a businessman just like himself. He believed in blurring boundaries including and now especially between the market and the state" (2017, $x v-x v i)$. In the world of today, nothing seems really outside commodification; one might say that we have reached (or nearly) the period of the end of capitalism foreseen by Marx in the Grundrisse based on its own universalisation (Marx 1972, 119-120), as Jameson summarised:

As far as socialism is concerned, a different Marx (that of the Grundrisse rather than that of Capital) always insisted that it would not be on the agenda until the world market had reached its limits and things and labour power became universally commodified. We are today far closer to that situation than in the time of either Marx or Lenin (Jameson 1998, 90-91). 
In this last phase of neoliberal capitalism, the haste of integration within the totalisation or reification process seems reinforced by new approaches to politics as in the case of Trump (and other world leaders), what has been denominated authoritarian capitalism (Fuchs 2017a), post-fascism (Traverso 2019), neo-fascism (Bellamy Foster 2017), or creeping fascism (Faulkner 2017). These authors, beyond their conceptual differences, agree that the marriage between capitalism and authoritarianism ${ }^{4}$ has as its ultimate goal the subordination of all social and political issues to the maximisation of economic benefit, in a corporatist style, the way in which a businessman runs his business; a strategy that is supported by a nationalist discourse, potentially expansive thanks to new technologies such as Twitter (Gounari 2018), that ensures the discrimination of a part of society (following Wallerstein, Fuchs $(2018,163)$ reminds us that racism and sexism are inseparable from nationalism) that is assumed to be non-productive and, therefore, of no economic interest for the nation-enterprise, breaking the link between democracy and liberalism (Kuttner 2018). A nation that has lost its social unity and where an increasing part of its members (as seen in US mid-term elections) have withdrawn sovereign legitimation from the ruling party and its leadership, having transformed the governmental apparatus into a branch of capital directed by a few and for a few (for the discussion on authoritarian populism, see also Kellner 2018; Abromeit 2018), realises nevertheless the progressive integration of all in that totalising global movement of reification and commodification that we have analysed above.

\subsection{Sartre's Dialectical Reason and the Neoliberal Subjectivity}

Can the neoliberal citizen have subjectivity when from so many flanks it has been proclaimed that the subject has died? Or to put it bluntly, can it be there subjectivity without a subject? If there is no subject, how can we talk about individuality; what does it really mean that we live in a society ever more individualistic, egotistic or selfish? The answer that I want to suggest, drawing from the above analysis, is that the individual of this era lives in a negated subjectivity; as a subject, it has died (on many occasions from different theoretical and practical backgrounds) and as a spectre it lives on within the economic market. This spectre can be recognised as a subjectivity that is no more: a negated subjectivity that renders the individual an object with mere exchange value.

And yet, we continue to refer to the individual of the neoliberal order with the term 'subjectivity'. I think it is worthwhile to qualify the thesis of this research to decide to what extent subjectivity refers to the subject as an autonomous, free and rational being and to what extent it is associated with just the opposite, the submission to the established order. Foucault, as is well known, used the term subjectification precisely in the sense of the conditioning of power over the individual and the production of a certain type of subject; in addition, according to this, and if we pay attention to Mitchell Dean's claim $(2017,19)$, neoliberalism would mean for Foucault the liberation of the subject from imposed subjectivities. But wouldn't that turn back to a subject that is autonomous and free?

\footnotetext{
${ }^{4}$ From the standpoint of critical theory, Fuchs $(2017 a, 63)$ argues that Trump's politics and ideology show four important features of authoritarianism: the leadership principle, nationalism, the friend/enemy scheme and patriarchy. This authoritarianism aims at the maximisation of the profit of Trump's real constituency: the ruling class of the state as a capitalist enterprise.
} 
It seems then that the problem is effectively linguistic to some extent. For, as Heartfield rightly points out, the term subject, from the Latin jacere, had meant in a primary sense those individuals who were subject to a certain hierarchy of power, such as, for example, the subjects of sovereign power; but in a more contemporary sense, with the establishment of democracy, the subject is understood as the individual who is subject to itself and owns its destiny (Heartfield 2006/2002, 19).

The term subjectivity tends to be associated indistinctly with both senses of the word subject. In this article, I have argued that it is precisely the subjectivity related to the subject, inasmuch as being free, autonomous, creative and rational, and in a word, complete in itself, which has been denied and, consequently, it has been shown as an absence functional to the affirmation within the totality; thus by means of the negation imposed by the (capitalist) neoliberal order, the consumer has been obtained as a moment of the integration of the thereby-negated subject in the process of totalisation of capital. The consumer according to this analysis, therefore, cannot be understood as a feature of neoliberal subjectivity but rather forms the positive determination or the affirmation of the totality in its process of the absolute integration of its parts; it is thus the consumer, in its progressive facets of satisfied, free and rational consumer, entrepreneur, digital user and creator of itself, no more than roles, masks or reifications (alienation) of the subject, who is not something separated from its temporal reification. Rather, the subject is the negated face, the negativity necessary for the affirmation of subsequent moments towards totalisation. These social roles, which constitute its form of life, are key players in capitalism together with taxpayers, who are consumers: "The successful entrepreneur, sovereign consumer and hard-working taxpayer, these are key players in the capitalist game today" (McGuigan 2014, 225). The subject appears as a spectre in the consumer and neoliberal citizen, alienated in its own being and identity. If the subject is in retreat, objectification is in advance, which means that the word 'objectification' fits better from this standpoint than subjectivity as a description of the process. The neoliberal individual, having lost its subjective (human) value, only lives on its projected value as an object in the space of the digital market. Therefore, from Sartrean dialectical reason, neoliberal capitalism, identified with the global market as a totality, aims to make objects or rather commodities from subjects, who are negated in terms of autonomy, freedom, creativity and rationality; that means that the analysis carried out shows that neoliberal subjectivity is not a positive characterisation of neoliberal individuals, but its negativity, what those individuals lack; and that lack is experienced as the trigger for implementing a form of life in which they become objects of the market in its integrating progression. ${ }^{5}$ Moreover, following Sartrean dialectic, subjectivity is thus revealed not in relation to an individual that is subjected to the system, as the term is usually understood from a Foucauldian standpoint, for the totality in which it is inscribed is not that of the master who is served by the subject, but that of the object and the objectification of everything within the field of the global market, which is not in an (inter)relation of subjectivity with the individuals, yet in a relation of reification. The neoliberal individual carries out a form of life which is objectified within the structure of the

\footnotetext{
${ }^{5} \mathrm{~A}$ vast literature on subjectivity has taken the term not to describe the concealed negativity in which has been posited the subject but to define the social roles played by individuals and the form of life imposed by neoliberal order; an example of this is Figueroa-Helland and Lindgren's paper in which the neoliberal subjectivity is identified with a plurality of positive characteristics such as Eurocentric, Consumerist, productivist, hetero-normative, male, masculine, Euro-Western, Bourgeois-capitalist (Figueroa-Helland and Lindgren 2016, 445).
} 
economic exchanges; the entire life of the individual has become the field of the market, and the market in the neoliberal order points to the total commodification of everything not to the subjectification, in the sense of making subjects, but profitable objects within the economic law of demand-offer.

The self is thus, according to the above, not individualistic but a mere object directed by the system in which it is integrated; a Sartrean being-in-itself, accessible by a multitude of potential consumers/user/watchers through the Web. The so-called generation Selfie thus has been wrongly accused of being egotistic or selfish, in this respect, for what the young man or woman that takes a selfie is showing is the emptiness or absence of use value in his/herself through their own objectification on the web-market, where transformed into a mere object (of desire or of envy or of like and dislike), they gain exchange value, sometimes at considerable moral or physical risks (a number of young people have died and continue to die in attempts at taking selfies in dangerous situations to impress the audience in the social network and get more likes: the exchange value of the times). The subjective experience is no longer an experience but the objectification of a moment through an image or a video (a post on the network). The subject experiences itself as an object on the net (as for instance in its online profile, which is more of a relational object), an object that has become a commodity for itself and for others; in this last respect, the reader must take into account the recent studies on Facebook and other social media and the light they are shedding on how these corporations obtain their revenues by making the users more engaged in posting, commenting or watching videos and images (see Vaidhyanathan 2018). If the user is an integrated element of the global market, where it is also reified in order to gain exchange value, in terms of subjectivity it is a negated subject, whose lack of subjective experience (or the experience of a negated subjectivity) becomes clear when not engaging in the (market) Internet. An example is offered by Jodi Dean, who refers to a report carried out by Turkle:

Reporting on her interviews with teenagers, Turkle describes young people waiting for connection, fearful of abandonment, and dependent on immediate responses from others even to have feelings. For example, seventeen-yearold Claudia has happy feelings as soon as she starts to text. Unlike a previous generation that might call someone to talk about feelings, when Claudia wants to have a feeling, she sends a text (J. Dean 2017, 15-16).

This initially surprising quotation does nothing more than confirm the existing dialectical relationship between the subject and its objectification (subjectivity and the digital market). The subject, only when it is an object; that is, when it is externalised and shown as an object for itself and for others within the digital world, shows its negated subjectivity, its desire, its needs, its incompleteness, and so on. In objectification and only objectification appears the neoliberal individual's negated subjectivity: the object, as the denier of subjectivity, has incorporated within it the latter as its negativity. Perhaps it is this dialectical relationship that produces the complexity of the phenomenon and its confusion. Of course, it is from this relationship that the death (or deaths) of the subject can be understood, and its survival in the same object that has killed it. In sum, a subject lives in denial by the object (the global market), and Dean's statement embraces and explains further what Heartfield states: "The only way to understand this mismatch is that the human subject persists, but in denial of its own subjectivity. Overwhelmed by the sense of 
powerfulness that grips each of us, we characterize our society in profoundly impersonal, even inhuman ways" (Heartfield 2006/2002, 238).

The neoliberal subject posited as a negation also has a negated subjectivity which can only be grasped as an absence, which, nevertheless, is the fundamental explanation of why individuals throw themselves into reproducing the form of life that integrates them within the totality, the global market (Harvey 2018). The latter wouldn't work if it didn't posit that negation in the first place. The absence is then the effect of positing its negation; what the individual experiences as an absence (no satisfaction, no self-esteem, no creativity, no freedom, no personal identity) leads them to the affirmation of the system in which they are included. Therefore, the positive characterisation of neoliberal subjectivity by means of attributes such as freedom, self-creation, consumerism, entrepreneurship, and so on, are only the reproduction of the imposed form of life itself (Tazzioli 2016), the process in which the individuals integrate themselves as objects or commodities (endowed now with proper exchange value) within the global market. In the critique of ideology such as that carried out by authors like Slavoj Žižek, this negated subjectivity, experienced as an absence that triggers individuals to integrate within the neoliberal order, can be read as the neoliberal ideology that makes possible the neoliberal order; with the words of the abovementioned philosopher: "We 'feel free' because we lack the very language to articulate our unfreedom [...] Our 'freedoms' themselves serve to mask and sustain our deeper unfreedom" (Žižek 2002b, 2).

\section{Conclusion}

I opened this article by delivering an account on the most accepted contemporary description of neoliberal subjectivity, and in doing so, I have assumed the existence of both elements: that of subject and that of neoliberal subjectivity. However, contrasting the proposal of neoliberal subjectivity with the post-modernist and poststructuralist claims of the time, which we have defined as that of neoliberal capitalism, about the death of the subject, a moment of contradiction has been reached to which, as defended throughout this article, only a dialectical approach could provide a solution. The dialectic rehabilitated by Sartre (2004/1960) has served to resolve this impasse by identifying the neoliberal individual as a denied subject (incomplete, desiring), posited as the first determination of the process of totalisation that presents all unity in a dialectical relationship with its internal moments. As the dialectic of realistic materialism suggests, by means of negations the totality is approaching that last moment of identification with itself and of totality without internal contradictions. In the historical process outlined since the 1970s, it has been shown how the neoliberal capitalist order, taken as a whole, has progressed in the reification of the subject since its first negation as part of the capitalist order. This reification process has been shaped in two fundamental aspects: 1. Integration of the individual in the totality as a positive determination of the logic of the market, aimed at an increasing reification of its desire, its freedom, its creativity and, finally, its identity. 2 . Homogenisation of the reified individual and negation of the subject, understood in its capacity of self-control and completeness, which is the implicit term negated (with the terms autonomous, free, creative and rational); and together with its negation, also at the last moment of the neoliberal era that we are living, the denial of everything that the subject held (the law, democracy, individuality, nature, etc.). From this analysis, it has been concluded that although the subject has died, denied by the totalising process of the global market, it maintains a spectral survival, as the negativity (negated subject) of the object in which the individual has become. But, on this 
background, to conclude, still a final discussion is in order: Is there a possible alternative for the birth of the subject? That is, under what conditions can the subject be born?

The birth of the subject is the counterpart of this prolonged death of the subject instantiated by the dialectic of the reifying process endowed by capitalism (and denounced by post-structuralist authors from epistemological backgrounds). But this process, as I have tried to show, is a totalisation from which, once the subject has been integrated, there is no return: the alternative to this society without a subject can only be envisioned as a new beginning after the final fulfilment of capitalist totalisation and its subsequent collapse. That means that small changes and adjustments can be pursued; but all of them might be absorbed within the totalising process, as the social movements of the last decades, i.e. the Me Too movement, Occupy or even political enterprises such as Syriza (2015 elections and capitulation), Podemos and others have proved, for resistance seems actually to be the engine of integration within totalisation (when the resistance is defeated and normalised). No multitude seems sufficient to change the structural mechanisms of a totalising and globalising process that has made possible precisely the emergence of these multitudes (Hardt and Negri 2009; Fuchs 2017a), whose means of resistance are facilitated by the same technologies and means of communication that the said capitalist totalisation puts at their service, absorbing and transforming individuals in objects whose subjectivity paradoxically only becomes present as the absence of a life that they feel lost and that they desire, seek and struggle to bring to light (since, as I have shown, the so-called neoliberal subjectivity is nothing more than a certain imposed praxis of a political-economic nature, and not characteristics of the subject itself). I understand that this statement is problematic. But it is inferred as a logical consequence of arguments endorsed in the previous sections of this article, along the lines of a certain Marxist interpretation of the Grundrisse and, of course, of Sartre's dialectical theorisation. And it is not contradictory as might be thought at first sight: when a similar position was adopted by Adorno and Horkheimer, the analysis and denouncement of the reifying steps of the process, as the latter said in the preface to his critical essays, has a purpose that is not purely revolutionary but is one of recognising and being alert, for "[giving] voice to what one knows and thereby perhaps to avert new terror remain the right of a man who is still really alive" (Horkheimer 2002/1968, viii).

After the ruins of capitalist totalisation, when the totality shows itself saturated and the social institutions of human life are recognised as absolutely useless and inefficient in their function as they have become, showing themselves reified, profitmaking-oriented and subsumed to market laws, a new society can be thought of as an alternative in which the subject could emerge. And this can only be a society free of centralising power and totalising processes, in which the social bonds are constituted by common temporal projects and emerge from imperious vital needs (not from created needs of consumption). Those seem to be the conditions of possibility for the subject to be born. In this sense, we can read the description of an anarcho-communist society in the work of Kropotkin, who emphasises the two principles of anarchist communism: 1) The abolition of individual property, which becomes the common property of society, and 2) the elimination of government, such that "the individual recovers his full liberty of initiative and action for satisfying, by means of free groups and federations - freely constituted all the infinitely varied needs of the human being" (Kropotkin 1905, 3). This anarchist society has the entire world in common, refusing individual property and the government as centralised 
ruling instances of power; therefore, only by mutual aid and support can a sort of social organisation grow (a society not regulated by positive law and elite's interests), led only by the purpose of helping each other at contingent situations (not as an structural longstanding institution but by voluntary association; see Graeber 2004, 3). This mutual aid tendency as part of the survival of the species is obviously very active in extreme situations such as the so-called "wild state" (Suter 2018), situations that endanger individual and social life, as Kropotkin put it: "When even the greatest calamities befell men - when whole countries were laid waste by wars, and whole populations were decimated by misery, or groaned under the yoke of tyranny - the same tendency continued to live in the villages and among the poorer classes in the towns; it still kept them together" $(1916,168)$.

The anarcho-communist society that we have just glimpsed in the words of Kropotkin (as he mentions situations of mutual aid and nothing more solid than that; for a non-reified concept of society, see Wallerstein 2000,119) must be held as the ideal society for the birth of the subject, once the current totalisation of capitalist world has concluded in the ever-more commodified and reified phase of neoliberal capitalism. This outlined society must be the counterpart of the current one, if it is to represent the negation of the negation of the subject: a society that "benefits all economically, socially, politically and culturally" (Fuchs 2018, 159) and holds as the legitimate embodiment the rational postulate of freedom conveyed by Chomsky, who, in turn, follows Bertrand Russell when he writes the following: "Those who adopt the common sense principle that freedom is our natural right and essential need will agree with Bertrand Russell that anarchism is the ultimate ideal to which society should approximate'. Structures of hierarchy and domination are fundamentally illegitimate" (Chomsky 2005, 156).

Therefore, if the arguments given in the previous paragraphs are accepted, then we must conclude that the only legitimate form of society is the one in which the subject can be born, that is, a society in which people are free to choose their mode of living without constraints or persuasion (pressure of public opinion by mass media and the institutions responsible for organising and favouring certain behaviour), and out of the reach of a totalising process that limits their ability to follow their personal vocation and lifestyle (Bagg 2018), constraining their possibility of actualising their freedom (the potentiality of it), through a subjectivity that is not imposed but, using Kant's words, the product of the "free play of imagination and understanding" (in terms of a free lawfulness; Ginsborg 2014).

\section{References}

Abromeit, John. 2018. Frankfurt School Critical Theory and the Persistence of Authoritarian Populism in the United States. In Critical Theory and Authoritarian Populism, edited by Jeremiah Morelock, 3-28. London: University of Westminster Press.

Agnew, John. 2005. Hegemony. The New Shape of Global Power. Philadelphia: Temple University Press.

Aristotle. 1959. Politics. London: William Heinemann Ltd.

Bagg, Samuel. 2018. Beyond the Search for the Subject: An Anti-Essentialist Ontology for Liberal Democracy. European Journal of Political Theory. Accessed May 19, 2019. https://doi.org/10.1177/1474885118763881.

Baudrillard, Jean. 1988. Selected Writings. Redwood City, CA: Stanford University Press.

Bauman, Zygmunt. 2000. Liquid Modernity. Cambridge: Polity Press.

Bellamy Foster, John. 2017. This is not Populism. Read Monthly Review 69 (2). Accessed May 19, 2019. https://monthlyreview.org/2017/06/01/this-is-not-populism/ 
Bourdieu, Pierre. 1990. The Logic of Practice. Redwood City, CA: Stanford University Press. Blühdorn, Ingolfur. 2017. Post-Capitalism, Post-Growth, Post-Consumerism? Eco-Political Hopes Beyond Sustainability. Global Discourse. Open Access. http://dx.doi.org/10. 1080/232699 95. 2017.1300415.

Chomsky, Noam. 2005. Chomsky on Anarchism. Edinburgh: AK Press.

Dean, Jodi. 2017. Nothing Personal. In Rethinking Neoliberalism, edited by Sanford F. Schram and Marianna Pavlovskaya, 3-22. New York: Routledge.

Dean, Mitchell. 2017. The Secret Life of Neoliberal Subjectivity. In Rethinking Neoliberalism, edited by Sanford F. Schram and Marianna Pavlovskaya, 23-40. New York: Routledge.

Engels, Friedrich. 1940. Dialectics of Nature. New York: International Publishers.

Faulkner, Neil. 2017. Creeping Fascism: Brexit, Trump, and the Rise of the Far Right. London: Public Reading Rooms.

Figueroa-Helland, Leonard and Tim Lindgren. 2016. What Goes Around Comes Around: From the Coloniality of Power to the Crisis of Civilization. Journal of World-Systems Research 22(2): 430-462.doi:10.5195/JWSR.20 16.631.

Foucault, Michel. 2008/2004. The Birth of Biopolitics. New York: Palgrave Macmillan.

Foucault, Michel. 1971/1966. The Order of Things. New York: Random House.

Fuchs, Christian. 2018. Racism, Nationalism and Right-Wing Extremism Online: The Austrian Presidential Election 2016 on Facebook. In Critical Theory and Authoritarian Populism, edited by Jeremiah Morelock, 157-206. London: University of Westminster Press.

Fuchs, Christian. 2017a. Donald Trump: A Critical Theory-Perspective on Authoritarian Capitalism. tripleC: Communication, Capitalism \& Critique. Open Access Journal for a Global Sustainable Information Society15(1): 1-72.

Fuchs, Christian. 2017b. Reflections on Michael Hardt and Antonio Negri's Book "Assembly". tripleC: Communication, Capitalism \& Critique. Open Access Journal for a Global Sustainable Information Society15(2): 851-865.

Fukuyama, Francis. 1992. The End of the History and the Last Man. New York: Macmillan.

Ginsborg, Hannah. 2014. Kant's Aesthetics and Teleology. The Stanford Encyclopedia of Philosophy, edited by Edward N. Zalta. Accessed May 19, 2019. https://plato.stanford.edu/archives/fall2014/entries/kant-aesthetics/

Gorz, André. 1989. Critique of Economic Reason. London: Verso.

Gounari, Panayota. 2018. Authoritarianism, Discourse and Social Media: Trump as the 'American Agitator'. In Critical Theory and Authoritarian Populism, edited by Jeremiah Morelock, 207-227. London: University of Westminster Press. https://doi.org/10.16997/book30.j

Graeber, David. 2004. Fragments of an Anarchist Anthropology. Chicago: Prickly Paradigm Press.

Hall, Donald Eugene. 2004. Subjectivity. New York: Routledge.

Hardt, Michael and Toni Negri. 2009. Commonwealth. Cambridge, MA: Harvard University Press.

Harvey, David. 2018. Universal Alienation. tripleC: Communication, Capitalism \& Critique. Open Access Journal for a Global Sustainable Information Society 16(2): 424-439.

Harvey, David. 2014. Seventeen Contradictions and the End of Capitalism. London: Profile Books Ltd.

Harvey, David. 2010. The Enigma of Capital and the Crises of Capitalism. Oxford: Oxford University Press.

Harvey, David. 2005. A Brief History of Neoliberalism. Oxford: Oxford University Press.

Heartfield, James. 2006/2002. The 'Death of the Subject' Explained. Sheffield: Sheffield Hallam UP.

Honneth, Axel. 2008. A new look at an old idea. Oxford: Oxford University Press.

Horkheimer, Max. 2002/1968. Critical theory: Selected essays. New York: Continuum. 
Hope, Wayne. 2018. Epochality, Global Capitalism and Ecology. tripleC: Communication, Capitalism \& Critique. Open Access Journal for a Global Sustainable Information Society 16(2): 562-576.

How, Alan. 2003. Critical Theory. Hampshire: Palgrave MacMillan.

Inayatullah, Naeem. 2013. Why do some people think they know what is good for others? In Global Politics,edited by Jenny Edkins and Maja Zehfuss, 430-453. New York: Routledge. Jameson, Fredric. 1998. The Cultural Turn. London: Verso.

Jameson, Fredric. 1991. Postmodernism, or The Cultural Logic of The Late Capitalism. Durham, NC: Duke University Press.

Jay, Martin. 1984. Marxism and totality. The adventures of a concept from Lukács to Habermas. Berkeley, CA: University of California Press.

Jumanji: Welcome to the Jungle. 2017. Directed by Jake Kasban. Culver City: Columbia Pictures; Matt Tolmach Productions; Seven Bucks Productions; Radar Pictures.

Kellner, Douglas. 2018. Donald Trump as Authoritarian Populist: A Frommian Analysis. In Critical Theory and Authoritarian Populism, edited by Jeremiah Morelock, 71-82. London: University of Westminster Press.

Kropotkin, Peter. 1916. Mutual Aid. New York: Alfred A. Knopf.

Kropotkin, Peter.1905. Anarchist Communism. London: Freedom office.

Kuttner, Robert. 2018. Can Democracy Survive Globalised Capitalism? New York: Norton Publishers.

Lukács, Georg.1971/1923. History and Class Consciousness. Translated by Rodney Livingstone. Cambridge, MA: MIT Press.

Lyotard, Jean François. 1989. The Postmodernist Condition: A Report on Knowledge. Manchester: Manchester University Press.

Manoussakis, John. 2014. Self and Time. In Post-Subjectivity, edited by Christoph Schmidt, Merav Mack and Andy German, 17-30. Newcastle: Cambridge Scholars Publishing.

Marx, Karl. 1972. Grundrisse. New York: Harper and Row Publishers.

Marx, Karl and Frederic Engels. 2010/1867. Capital I. Collected Works. Vol. 35 [e-book]. London: Lawrence and Wishart.

Mason, Paul. 2015. Post-Capitalism: A Guide to Our Future. London: Penguin Books.

Motzkin, Gabriel. 2014. Post-Subjectivity and Historical Consciousness. In Post-Subjectivity, edited by Christoph Schmidt, Merav Mack and Andy German, 9-15. Newcastle: Cambridge Scholars Publishing.

McGuigan, Jim. 2014. The Neoliberal Self.Culture Unbound 6 (1): 223-240.

McGuigan, Jim. 2006/1999. Modern and Postmodern. Maidenhead, Berkshire: Open University Press.

Pitts, Frederick Harry, and Ana Dinerstein. 2017. Postcapitalism, Basic Income and The End of Work: A Critique and Alternative. Bath Papers in International Development and WellBeing 55. Bath: Centre for Development Studies at University of Bath.

Plehwe, Dieter, Bernhard Walpen, and Gisela Neunhöffer, eds. 2006. Neoliberal Hegemony. A Global Critique. London: Routledge.

Prodnik, Jernej A. 2014. A Seeping Commodification: The Long Revolution in the Proliferation of Communication Commodities. tripleC: Communication, Capitalism \& Critique. Open Access Journal for a Global Sustainable Information Society12(1): 142168.

Sanford F. Schram and Marianna Pavlovskaya, eds. 2017. Rethinking Neoliberalism. New York: Routledge.

Sartre, Jean-Paul. 2004/1960. Critique of Dialectical Reason: Volume One. London: Verso.

Schmidt, Christoph. 2014. Subjectivities After the Death of the Subject. In Post-Subjectivity, edited by Christoph Schmidt, Merav Mack and Andy German, 1-8. Newcastle: Cambridge Scholars Publishing.

Schmidt, Christoph, Merav Mack and Andy German, eds. 2014. Post-Subjectivity. Newcastle: Cambridge Scholars Publishing. 
Sklair, Leslie. 2016. The End of the World or the End of Capitalism? Global Dialogue:

Newsletter for the International Sociological Association. March: 22-23.

Suter, Keith. 2018. The Future of the Nation-State in an Era of Globalization. Cadmus 3(4): 32-38.

Tazzioli, Martina. 2016. Revisiting the Omnes et Singulatim Bond: The Production of Irregular Conducts and the Biopolitics of the Governed. Foucault Studies 21 (1): 98-116.

Traverso, Enzo. 2019. The New Faces of Fascism. Populism and the Far Right [2nd edition]. London: Verso.

Vaidhyanathan, Siva. 2018. Antisocial Media: How Facebook Disconnects us and Undermines Democracy. New York: Oxford University Press.

Varoufakis, Yaris. 2011. The Global Minotaur. London: Zed Books.

Verdouw, Julia Joanne. 2017. The Subject Who Thinks Economically? Comparative Money Subjectivities in Neoliberal Context. Journal of Sociology 53 (3): 523- 540. https://doi.org/10.1177/1440783316662717

Wagler, Ron. 2009. Foucault, The Consumer Culture and Environmental Degradation, Ethics, Place and Environment12 (3): 331336. doi:10.1080/13668790903195628

Wallerstein, Immanuel. 2000. The Essential Wallerstein. New York: The New Press.

Weber, Max. 2005/1930. The Protestant Ethic and the Spirit of Capitalism. London: Routledge.

Wittel, Andreas. 2013. Counter-Commodification: The Economy of Contribution in the Digital Commons. Culture and Organization 19 (4): 314-331.

Yuran, Noam. 2019. Being and Television: Producing the Demand to Individualise. tripleC: Communication, Capitalism \& Critique. Open Access Journal for a Global Sustainable Information Society 17(1): 56-71.

Žižek, Slavoj. 2002a. A Plea for Leninist Intolerance. Critical Inquiry 28 (1): 542-543.

Žižek, Slavoj. 2002b. Welcome to the Desert of the Real! London: Verso.

\begin{abstract}
About the Author
Daniel Rueda Garrido

Daniel Rueda Garrido is a faculty member of Hebei Normal University, China. Currently, he teaches Rhetoric, Literature and Critical thinking. He is a PhD with a thesis on Philosophy of Action defended at the University of Madrid (UNED), Spain. He is the author of two philosophical novels and one essay on Philosophy of Action and a number of academic publications, the most recent being a paper in Review of Contemporary Philosophy titled Towards a Cultural Phenomenology of Actions and Forms of Life (2019).
\end{abstract}

